\title{
BIOADSORPSI Hg(II) OLEH PATI SAGU TAUT SILANG FOSFAT
}

\author{
[Bioadsorption of $\mathrm{Hg}(\mathrm{II})$ by Crosslinked Sago Starch Phosphate]
}

\author{
Jorion Romengga ${ }^{1 / *}$, Tun Tedja Irawadi2) dan Sri Sugiarti2) \\ 1) Jurusan Kimia, Fakultas Matematika dan IImu Pengetahuan Alam, Universitas Tanjungpura, Pontianak \\ 2) Departemen Kimia, Fakultas Matematika dan IImu Pengetahuan Alam, Institut Pertanian Bogor, Bogor
}

Diterima 15 September 2011 / Disetujui 09 Juli 2012

\begin{abstract}
Crosslinked-sago-starch-phosphate ( $\mathrm{SgP}$ ) has been successfully synthesized from native sago starch (Sg) and $\mathrm{Na}_{2} \mathrm{HPO}_{4}-\mathrm{NaH}_{2} \mathrm{PO}_{4}$ in an acidic condition. The compound was designed as bioadsorbent for removing $\mathrm{Hg}(\mathrm{Il})$ inside human digestion tract as shown by in vitro test. The bioadsorption followed pseudo-second order of reaction kinetic and Freundlich equation as chemisorption. As a result, $21 \%$ of $\mathrm{Hg}(\mathrm{II})$ was removed at $\mathrm{pH}$ of 6.80 and reached the isothermal equilibrium of the bioadsorption at $\mathrm{pH}$ of 5.80 and 8.60 for $29.95 \%$ and $31.39 \%$, respectively. The result showed that $\mathrm{SgP}$ is more feasible than activated carbon to be used as bioadsorbent in removing $\mathrm{Hg}(\mathrm{II})$ in human digestion tract as proved by in vitro system.
\end{abstract}

Keywords: bioadsorption, phosphate crosslinked, $\mathrm{Hg}(\mathrm{II})$, phosphate, sago starch

\begin{abstract}
ABSTRAK
Pati sagu taut silang fosfat (SgP) telah berhasil disintesis dari pati sagu natif $(\mathrm{Sg})$ dan $\mathrm{Na}_{2} \mathrm{HPO}_{4}-\mathrm{NaH}_{2} \mathrm{PO}_{4}$ dalam suasana asam. SgP tersebut didesain sebagai bioadsorben untuk menjerap $\mathrm{Hg}(\mathrm{II})$ yang terdapat dalam saluran pencernaan manusia yang dilakukan secara in vitro. Proses bioadsorpsi tersebut memenuhi kinetika reaksi orde kedua semu dan persamaan Freundlich sebagai kemisorpsi. Adapun hasilnya menunjukkan bahwa $21 \%$ ion $\mathrm{Hg}(\mathrm{II})$ telah dijerap pada $\mathrm{pH}$ 6,80 dan mencapai kesetimbangan isotermal bioadsorpsi pada pH 5,80-8,60 sebesar 29,95\% dan $31,39 \%$, secara berturut-turut. Hal ini menunjukkan bahwa SgP lebih berguna daripada karbon aktif sebagai bioadsorben umum yang digunakan untuk menjerap $\mathrm{Hg}(\mathrm{II})$ pada saluran pencernaan manusia yang dibuktikan secara in vitro.
\end{abstract}

Kata kunci: bioadsorpsi, taut silang fosfat, $\mathrm{Hg}(\mathrm{II})$, fosfat, pati sagu

\section{PENDAHULUAN}

Pada saat ini, pencemaran logam berat menjadi salah satu topik utama pencemaran lingkungan air. Hal ini disebabkan logam berat dapat terikat dengan material organik yang terlarut di dalam air sehingga terjadi proses bioakumulasi, biotransformasi, dan biomagnifikasi dalam rantai makanan di alam (Gyliene dan Visniakova, 2008; Wan et al., 2010). Salah satu jenis logam berat dengan toksisitas tinggi yang sering mencemari lingkungan air adalah merkuri. Merkuri di dalam air berada dalam bentuk $\mathrm{Hg}(\mathrm{II})$. United State Environmental Protection Agency menetapkan ambang batas $\mathrm{Hg}(\mathrm{II})$ dalam air adalah $0,300 \mathrm{ppb}$. $\mathrm{Hg}$ (II) dapat terdeposit dalam tubuh manusia terutama pada bagian otak, kulit, hati, pankreas, dan miokardium. Adapun gangguan yang ditimbulkan tersebut antara lain gangguan sistem saraf pusat, pernapasan, pencernaan, dan iritasi kulit (Farooq et al., 2010).

Beberapa metode untuk menghilangkan kontaminasi logam berat di dalam air telah dilakukan. Metode tersebut di antaranya adalah koagulasi, flokulasi, evaporasi, presipitasi, elektrokoagulasi, pertukaran ion, pemisahan membran, dan bioadsorpsi (Aziz et al., 2008; Chen et al., 2011; Zakhama et al.,

*Korespondensi Penulis:

E-mail: rion_220687@yahoo.co.id; Hp: +6285252069729; +628989567876
2011). Bioadsorpsi merupakan suatu metode penghilangan kontaminasi logam berat yang paling efektif dan efisien. Hal ini disebabkan bioadsorpsi menggunakan bahan material yang murah, terbiodegradasi, dan dapat digunakan berulang kali. Sekarang ini, pati termodifikasi khususnya pati taut silang fosfat merupakan biomaterial adsorben yang ekonomis, efektif, dan mudah diaplikasikan (Xing et al., 2006; Ding et al., 2011).

Pati taut silang fosfat merupakan salah satu biomaterial yang dapat diaplikasikan sebagai bioadsorben. Modifikasi pati tersebut memiliki syarat khusus, yaitu bahan baku pati harus memiliki kadar amilosa $\geq 25 \%$ (Blennow et al., 2002). Salah satu tipe pati yang prospektif tersebut dan tersedia di Indonesia adalah pati sagu (Sg) (Metroxylon sago). Hal ini disebabkan pati sagu memiliki kadar amilosa $24-31 \%$. Selain itu, produksi pati sagu di Indonesia sekitar 210 juta ton per tahun dan hanya 5 juta ton per tahun yang digunakan sebagai bahan pangan pokok (Ahmad et al., 1999; BPBPI, 2007). Hal ini menunjukkan ketersediaan $\mathrm{Sg}$ untuk dapat dimodifikasi menjadi pati sagu taut silang fosfat (SgP) sebagai bioadsorben.

Pati sagu taut silang fosfat berpotensi sebagai bioadsorben $\mathrm{Hg}(\mathrm{II})$. Hal ini didasarkan adanya efek ligan, muatan parsial negatif, bilangan koordinasi, dan geometri gugus fosfat taut silang pada SgP (Chen et al., 2011). Selain itu, resistansi SgP terhadap gangguan fisik, kimia, dan biologis menjadikan $\mathrm{SgP}$ 
dapat diaplikasikan sebagai bioadsorben $\mathrm{Hg}(\mathrm{II})$ dalam sistem pencernaan manusia. Hingga saat ini, belum ada kajian tentang aplikasi $\mathrm{SgP}$ sebagai bioadsorben $\mathrm{Hg}(\mathrm{II})$ yang terpapar dalam tubuh manusia. Hal ini disebabkan $\mathrm{SgP}$ baru marak disintesis dan diaplikasikan sebagai pati termodifikasi yang terbatas hanya sebagai agen pengental dan pelepasan obat (BeMiller dan Whistler, 2009; Li et al., 2009; Manoi dan Rizvi, 2010).

Tujuan penelitian ini adalah menentukan kapasitas maksimum adsorpsi $\mathrm{Hg}(\mathrm{II})$ oleh $\mathrm{SgP}$ sebagai bioadsorben dalam sistem pencernaan manusia secara in vitro. Hipotesis yang mendasari penelitian ini, ialah (1) $\mathrm{Sg}$ memiliki gugus hidroksil bebas pada atom $\mathrm{C}_{3}$ dan $\mathrm{C}_{6}$ unit anhidroglukosa yang dapat dimodifikasi oleh gugus fosfat anorganik secara esterifikasi membentuk SgP; (2) SgP berpotensi sebagai bioadsorben $\mathrm{Hg}(\mathrm{II})$ karena adanya gugus taut silang fosfat yang stabil. Oleh karena itu, penelitian ini diharapkan mampu memberikan informasi ilmiah mengenai potensi SgP sebagai bioadsorben $\mathrm{Hg}(\mathrm{II})$ dalam sistem pencernaan manusia.

\section{BAHAN DAN METODE}

\section{Bahan}

Sampel Sg (amilosa $\sim 26 \%$, kelengasan 10\%, dan diameter molekul $\sim 10 \mu \mathrm{m})$ dibeli dari pasar tradisional Laladon, Kabupaten Bogor, Jawa Barat. Reagen $\mathrm{Hg}\left(\mathrm{NO}_{3}\right)_{2} \cdot \mathrm{H}_{2} \mathrm{O}$ p.a, $\mathrm{NaH}_{2} \mathrm{PO}_{4} \cdot \mathrm{H}_{2} \mathrm{O}$ p.a, dan $\mathrm{Na}_{2} \mathrm{HPO}_{4} .2 \mathrm{H}_{2} \mathrm{O}$ p.a, diperoleh dari Merck (Darmstadt, Jerman). Enzyplex (a-amilase) diproduksi oleh PT Medifarma Laboratories (Westmont Pharmaceuticals Ltd, USA).

\section{Sintesis SgP}

Sintesis $\mathrm{SgP}$ pada penelitian ini mengacu pada metode yang dilakukan oleh Romengga et al. (2011). Pati sagu (Sg) disuspensikan menjadi 35\% dalam larutan 0,1 $\mathrm{M} \mathrm{Na}_{2} \mathrm{HPO}_{4}$ dan larutan 0,1 $\mathrm{M} \mathrm{NaH}_{2} \mathrm{PO}_{4}$ (3:2) (pH awal 6,89 diukur dengan $\mathrm{pH}-$ meter (TOA HM-20S), serta diatur pH-nya hingga 6,50 dengan penambahan beberapa tetes $0,01 \mathrm{M} \mathrm{HCl}$ dan $0,01 \mathrm{M} \mathrm{NaOH}$. Suspensi tersebut dipanaskan pada suhu $40^{\circ} \mathrm{C}$ dan diaduk dengan kecepatan 300 rpm selama 20 menit. Selanjutnya, endapan yang terbentuk dipisahkan dari filtrat dengan disaring menggunakan kertas saring Whatmann 40. Endapan tersebut dikeringkan di dalam oven $\left(80 \pm 5^{\circ} \mathrm{C}\right)$ selama 24 jam, dan diayak dengan ayakan $10 \mu \mathrm{m}$. Butiran $\mathrm{SgP}$ yang diperoleh selanjutnya disimpan dalam wadah kedap udara sebelum digunakan lebih lanjut selama penelitian berlangsung.

\section{Analisis spektrofotometri TFIM}

Perbedaan gugus fungsi $\mathrm{Sg}$ dan $\mathrm{SgP}$ dianalisis secara spektrofotometeri inframerah dengan spektrofotometer Transformasi Fuorier Inframerah (TFIM) (Vector-33). Sebanyak 1\% sampel dalam pelet $\mathrm{KBr}$ diuji dengan spektrofotometer TFIM pada panjang gelombang $4000-400 \mathrm{~nm}$.

\section{Analisis viskosa}

Pada penelitian ini, analisis viskosa $\mathrm{Sg}$ dan $\mathrm{SgP}$ berdasarkan pada metode Karim et al. (2008) menggunakan penganalisis viskosa cepat (Tecmaster, Australia).

\section{Penentuan nilai derajat substitusi fosfat (DSp) (Igura dan} Okazaki, 2010)

Nilai DSp dihitung berdasarkan nisbah Absorbans relatif CO-P yang didapat pada spektrum TFIM SgP berdasarkan persamaan 1.

$\mathrm{DSp}=\mathrm{A}_{1200} \mathrm{~cm}^{-1} / \mathrm{A}_{990} \mathrm{~cm}^{-1}$ 1

\section{Penentuan adsorpsi $\mathrm{Hg}$ (II) oleh SgP}

Sebanyak 0,100 g SgP ditambahkan ke dalam $50 \mathrm{~mL}$ larutan $\mathrm{Hg}(\mathrm{II})$ dengan konsentrasi awal 100 ppm. Adapun pH larutan awal dan akhir dijaga konstan pada $\mathrm{pH} \sim 3,00$ dengan laju pengadukan $150 \mathrm{rpm}$ pada suhu $30^{\circ} \mathrm{C}$ selama 1 jam. Selanjutnya, campuran tersebut disaring dan konsentrasi larutan $\mathrm{Hg}(\mathrm{II})$ akhir dihitung secara kolorimetrik dengan spektrofotometer UV/Vis pada $\lambda_{\text {maks }}=575 \mathrm{~nm}$ dengan penambahan larutan $I_{2} 2 \%$ sebagai senyawa pengompleks (Amitava, 2010). Kapasitas adsorpsi $\mathrm{Hg}(\mathrm{II})$, yaitu $(\mathrm{Q})(\mathrm{mg} / \mathrm{g})$ dihitung berdasarkan persamaan 2.

$$
Q=\left(C_{i}-C_{f}\right) \cdot V / W
$$

Dengan $C_{i}(\mathrm{mg} / \mathrm{mL})$ dan $C_{f}(\mathrm{mg} / \mathrm{mL})$ menyatakan konsentrasi awal dan akhir larutan $\mathrm{Hg}(\mathrm{II})$, secara berturut-turut; $\mathrm{V}$ menyatakan volume larutan $(\mathrm{mL})$; dan $\mathrm{W}$ menyatakan massa SgP yang digunakan $(g)$.

\section{Studi kinetika adsorpsi $\mathrm{Hg}$ (II) oleh SgP}

Sebanyak $0,100 \mathrm{~g} \mathrm{SgP}$ ditambahkan ke dalam $50 \mathrm{~mL}$ larutan $\mathrm{Hg}(\mathrm{II}) 100 \mathrm{ppm}$. Parameter kinetika seperti $\mathrm{pH}$ awal diatur pada $\sim 3,00$ dan ragam waktu adsorpsi 0 sampai 60 menit. Pada akhir waktu tersebut, campuran disaring dan dipisahkan filtratnya. Kapasitas adsorpsi $\mathrm{Hg}(\mathrm{II})$ akhir dalam filtrat tersebut dihitung berdasarkan persamaan 2. Pada studi ini, persamaan kinetika adsorpsi orde pertama semu dan kedua semu digunakan. Penggunaan kedua persamaan tersebut dilakukan untuk mengetahui adanya interaksi antarmolekul (Ding et al., 2011). Kedua persamaan tersebut dinyatakan pada persamaan 3 dan 4 , secara berturut-turut.

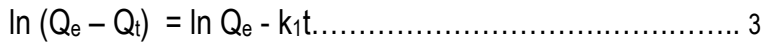

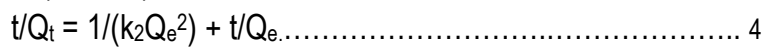

Dengan, $\mathrm{Q}_{\mathrm{e}}$ dan $\mathrm{Q}_{\mathrm{t}}$ menyatakan kapasitas adsorpsi $\mathrm{Hg}(\mathrm{II})$ $(\mathrm{mg} / \mathrm{g})$ pada saat kesetimbangan dan pada waktu tertentu, secara berturut-turut; $\mathrm{k}_{1}\left(\mathrm{~min}^{-1}\right)$ dan $\mathrm{k}_{2}$ (g/mg.min) menyatakan konstanta kinetika orde pertama semu dan orde kedua semu, secara berturut-turut.

\section{Studi kesetimbangan adsorpsi $\mathrm{Hg}(\mathrm{II})$ oleh SgP}

Sebanyak $50 \mathrm{~mL}$ larutan $\mathrm{Hg}(\mathrm{II})$ dengan variasi konsentrasi awal (0-250 ppm) diatur pada $\mathrm{pH}$ awal $\sim 3,00$ dengan laju pengadukan $150 \mathrm{rpm}$ pada suhu $30^{\circ} \mathrm{C}$ selama 1 jam. Pada akhir waktu tersebut, campuran tersebut disaring dan diambil filtratnya. Konsentrasi $\mathrm{Hg}(\mathrm{II})$ yang diadsorpsi oleh $\mathrm{SgP}$ pada variasi konsetrasi larutan $\mathrm{Hg}(\mathrm{II})$ tersebut ditentukan secara kolorimetrik pada $\lambda_{\text {maks }}=575 \mathrm{~nm}$ (spektrofotometer UV/Vis 
(Spectronic 20D+) menggunakan larutan $\mathrm{I}_{2} 2 \%$. Kapasitas adsorpsi $\mathrm{Hg}(\mathrm{II})$ yang diadsorpsi oleh $\mathrm{SgP}$ dengan variasi konsentrasi larutan $\mathrm{Hg}(\mathrm{II})$ dihitung berdasarkan persamaan 1. Adapun persamaan kesetimbangan adsorpsi $\mathrm{Hg}(\mathrm{II})$ oleh $\mathrm{SgP}$ yang digunakan pada penelitian ini ada 3 , yaitu persamaan Langmuir, Freundlisch, dan Dubinin-Radushkevich. Ketiga persamaan tersebut dinyatakan pada persamaan 5,6 , dan 7 , secara berturut-turut.

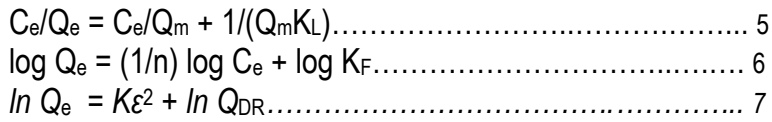

Dengan $\mathrm{C}_{\mathrm{e}}$ merupakan konsentrasi kesetimbangan $\mathrm{Hg}(\mathrm{II})$ (mg/L); $Q_{e}$ merupakan kapasitas adsorpsi $\mathrm{Hg}(\mathrm{II})$ pada saat kesetimbangan $(\mathrm{mg} / \mathrm{g}) ; Q_{m}(\mathrm{mg} / \mathrm{g}), K_{F}(\mathrm{~L} / \mathrm{g})$, dan $Q_{D R}(\mathrm{mg} / \mathrm{g})$ merupakan kapasitas adsorpsi $\mathrm{Hg}(\mathrm{Il})$ maksimum pada persamaan Langmuir, Freundlich, dan Dubinin-Radushkevich, secara berturut-turut. Nilai $\mathrm{K}_{\mathrm{L}}(\mathrm{L} / \mathrm{mg}), \quad \varepsilon(\mathrm{kJ} / \mathrm{mol})$, dan $\mathrm{K}$ $\left(\mathrm{mol}^{2} / \mathrm{kJ}^{2}\right)$ merupakan konstanta Langmuir, potensial Polanyi (jumlah energi ikatan adsorpsi), dan Dubinin-Radushkevich, secara berturut-turut. Nilai $\mathrm{n}$ (tanpa satuan) merupakan intensitas adsorpsi. Berdasarkan nilai $\mathrm{K}$ tersebut, maka nilai energi aktivasi biadsorpsi $\mathrm{Hg}(\mathrm{II})$ oleh $\mathrm{SgP}$ dapat dihitung berdasarkan persamaan 8 (Itodo dan Itodo, 2010; Chen et al., 2011).

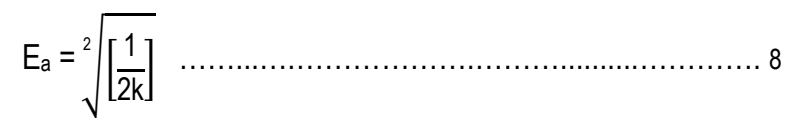

\section{Uji resistansi}

Sebanyak 0,100-0,600 g Sg dan SgP diuji nilai resistansinya pada ragam $\mathrm{pH} 1,50 ; 6,80,5,80$; dan 8,60 selama 3 jam, 2 jam, 2 jam, dan 1 jam, pada suhu konstan $37^{\circ} \mathrm{C}$ secara berturutturut. Massa resistan SgP yang didapat selanjutnya diaplikasikan sebagai bioadsorben $\mathrm{Hg}(\mathrm{II})$ secara in vitro sistem pencernaan manusia.

\section{Bioadsorpsi $\mathrm{Hg}$ (II) oleh SgP secara in vitro sistem pencernaan manusia}

Sejumlah $\mathrm{SgP}$ yang telah dihitung massa resistansinya disuspensikan ke dalam $50 \mathrm{~mL}$ larutan $\mathrm{Hg}(\mathrm{Il})$ (100 ppm) yang dijaga konstan pada pH 1,50 selama 3 jam; 6,80 selama 2 jam (dengan penambahan 500 IU a-amilase); 5,80 selama 2 jam; dan 8,60 selama 1 jam, secara berturut-turut. Suspensi tersebut diaduk dengan laju $300 \mathrm{rpm}$ pada suhu $38^{\circ} \mathrm{C}$. Selanjutnya, suspensi tersebut disaring untuk memisahkan filtrat dan residunya. Residu yang didapat dikeringanginkan dan dilarutkan ke dalam larutan $\mathrm{HNO}_{3}(0,1 \mathrm{M} ; 25 \mathrm{~mL})$ pada suhu ruang selama 1 jam. Konsentrasi $\mathrm{Hg}(\mathrm{II})$ teradsorpsi dalam $\mathrm{SgP}$ tersebut setara dengan konsentrasi $\mathrm{Hg}(\mathrm{II})$ yang terdesorpsi ke dalam larutan $0,1 \mathrm{M} \mathrm{HNO}_{3}$ dan dihitung secara kolorimetrik dengan spektrofotometer UV/Vis pada $\lambda_{\text {maks }}=575 \mathrm{~nm}$.

\section{Analisis data}

Semua data yang didapat dalam penelitian ini dilakukan pengulangan sebanyak enam kali dan dianalisis secara statistik menggunakan Microsoft Excel 2007.

\section{HASIL DAN PEMBAHASAN}

\section{Spektrum TFIM dari SgP}

Pada penelitian ini, spektrum TFIM dari $\mathrm{Sg}$ dan $\mathrm{SgP}$ menunjukkan pola serapan yang berbeda (Gambar 1). Pada Gambar 1B, terdapat 1 puncak serapan baru, yaitu $2362 \mathrm{~cm}^{-1}$ (diester fosfat). Pada sisi lain, kedua spektrum TFIM1200 $\mathrm{cm}^{-1}$ (ayunan $\mathrm{P}=0$ ), dan $990 \mathrm{~cm}^{-1}$ (regangan C-O-P) (Silverstein et al., 2005; Wanrosli et al., 2011). Berdasarkan nisbah Absorbans relatif, nilai DSp SgP sebesar 0,355 (Tabel 1). Terjadinya substitusi dan pembentukkan taut silang tersebut juga dapat dibuktikan dengan adanya perbedaan viskositas puncak antara $\mathrm{Sg}$ dan $\mathrm{SgP}$ (Gambar 2). Tingginya selisih antara viskositas puncak $\mathrm{SgP}$ dan $\mathrm{Sg}$ menunjukkan bahwa adanya substitusi gugus fosfat yang tinggi dan membentuk taut silang pada SgP sebagai suatu pati resistan (Karim et al., 2008; BeMiller dan Whistler, 2009). Hal ini menunjukkan bahwa telah terjadi susbtitusi dan pembentukan taut silang fosfat pada $\mathrm{SgP}$, baik berdasarkan spktrum FTIR maupun analisis viskosa cepat.

Tabel 1. Absorbans relatif ikatan C-O-P pada SgP

\begin{tabular}{ccc}
\hline \multirow{2}{*}{ Sampel } & \multicolumn{2}{c}{ Absorbans Relatif } \\
\cline { 2 - 3 } & $1200 \mathrm{~cm}^{-1} / 1325 \mathrm{~cm}^{-1}$ & $990 \mathrm{~cm}^{-1} / 1325 \mathrm{~cm}^{-1}$ \\
\hline $\mathrm{Sg}$ & 1,04 & 0,05 \\
$\mathrm{SgP}$ & 1,19 & 3,35 \\
\hline
\end{tabular}

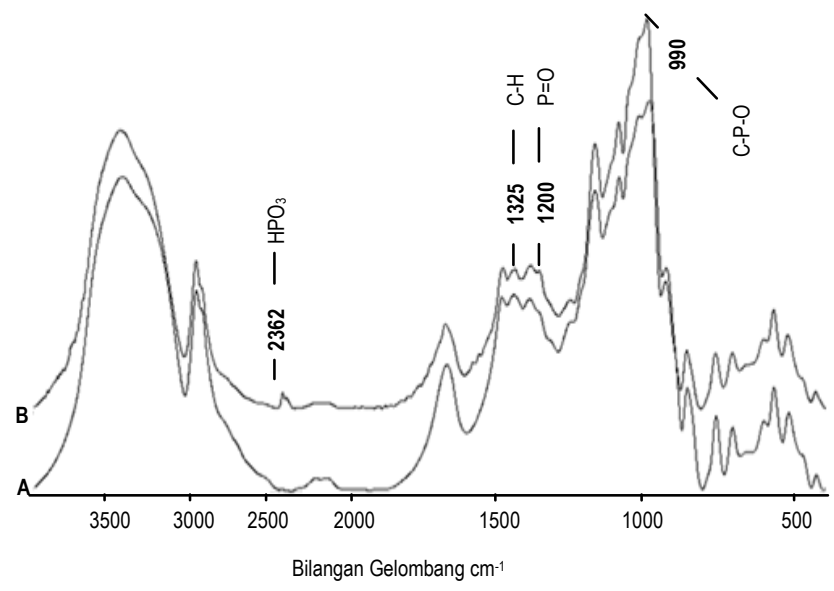

Gambar 1. Spektrum TFIM: A. Sg; B. SgP

\section{Kinetika adsorpsi $\mathrm{Hg}(\mathrm{II})$}

Pada penelitian ini, kinetika adsorpsi $\mathrm{Hg}(\mathrm{II})$ mengikuti kinetika adsorpsi orde kedua semu (Tabel 2). Hal ini menunjukkan terjadinya kemisorpsi yang melibatkan daya tarik valensi atom logam dan gugus fungsi fosfat melalui pengelatan dan pengompleksan antara SgP dan $\mathrm{Hg}(\mathrm{II})$ (Gupta et al., 2010; Chen et al., 2011). Hal ini disebabkan adanya sisi koordinasi multidentat pada gugus fosfat (Wan Ngah et al., 2011). Ikatan $\mathrm{P}=\mathrm{O}, \mathrm{P}-\mathrm{O}$, dan $\mathrm{OH}$ diduga mengompleks dengan ion $\mathrm{Hg}(\mathrm{II})$. Ketiga gugus tersebut mampu berinteraksi dengan $\mathrm{Hg}$ (II) akibat adanya efek asam basa keras lunak (Gambar 3) (Lippard dan Berg, 1994). 


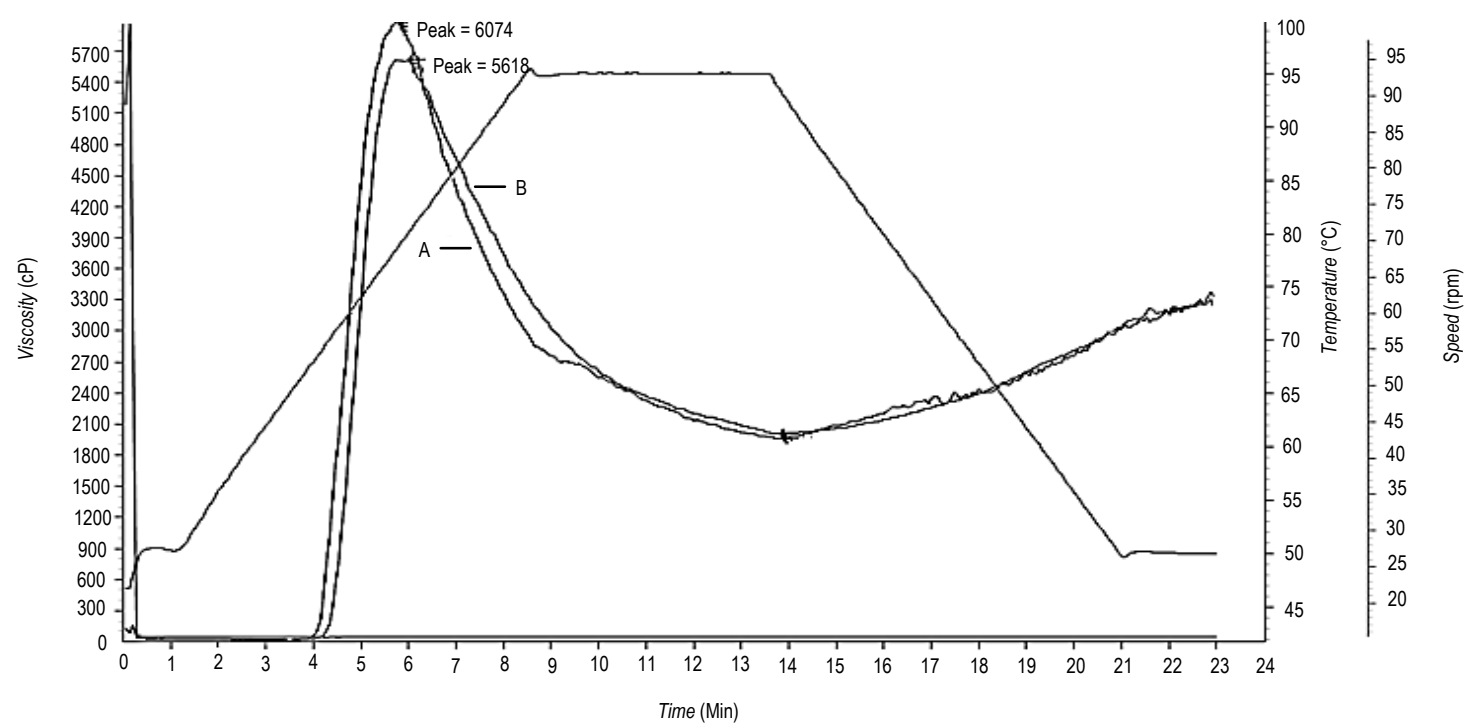

Gambar 2. Spektrum Analisis Viskositas Cepat: A. Sg; B. SgP

Tabel 2. Parameter kinetika bioadsorpsi $\mathrm{Hg}(\mathrm{II})$ oleh SgP

\begin{tabular}{lccc}
\hline \multicolumn{1}{c}{ Tipe Kinetika Adsorpsi } & $\mathrm{Q}_{\mathrm{e}}$ & $\mathrm{k}_{\mathrm{n}}$ & $\mathrm{R}^{2}$ \\
\hline Orde pertama semu & 53,464 & $-0,056$ & 0,934 \\
Orde kedua semu & 57,803 & 0,002 & 0,992 \\
\hline
\end{tabular}

\section{Kesetimbangan adsorpsi $\mathrm{Hg}$ (II) oleh SgP}

Pada penelitian ini, ekuilibrium bioadsorpsi $\mathrm{Hg}(\mathrm{II})$ memenuhi persamaan Freundlisch (Tabel 3). Pada penelitian ini, besarnya energi ikatan adsorpsi yang didapat dari nilai $\varepsilon$ sebesar 21,765 $\mathrm{kJ} / \mathrm{mol}$. Adapun nilai $\mathrm{E}_{\mathrm{a}} \mathrm{Hg}(\mathrm{II})$ oleh $\mathrm{SgP}$ yang diturunkan dari persamaan Dubinin-Radushkevich sebesar 8,452 kJ/mol (Persamaan 8). Hal ini menyatakan bahwa bioadsorpsi $\mathrm{Hg}(\mathrm{II})$ oleh $\mathrm{SgP}$ merupakan kemisorpsi melalui reaksi tukar kation (Gambar 3) (Güney et al., 2007; Gupta et al., 2010).

Tabel 3. Parameter isotermal Langmuir, Freundlisch, dan DubininRadushkevich

\begin{tabular}{lccc}
\hline \multicolumn{1}{c}{ Tipe Adsorpsi } & \multicolumn{3}{c}{ Parameter } \\
\hline Langmuir & $\mathrm{Qm}$ & $\mathrm{K} \mathrm{L}$ & $\mathrm{R}^{2}$ \\
& 8,333 & 0,12 & 0,833 \\
Freundlisch & $\mathrm{K}_{\mathrm{F}}$ & $1 / \mathrm{n}$ & $\mathrm{R}^{2}$ \\
& 1,022 & 0,036 & 0,999 \\
Dubinin-Radushkevich & $\mathrm{In} \mathrm{QDR}_{\mathrm{DR}}$ & $\mathrm{K}$ & $\mathrm{R}^{2}$ \\
& 3,316 & $-0,007$ & 0,985 \\
\hline
\end{tabular}

\section{Uji in vitro bioadsorpsi $\mathrm{Hg}$ (II) oleh SgP}

Sistem in vitro pencernaan manusia yang digunakan pada penelitian ini dilakukan dengan meragamkan nilai $\mathrm{pH}$ serupa dengan sistem pencernaan manusia (Gambar 4) (Murray et al., 2003). Adapun resistansi SgP yang digunakan pada penelitian ini diuji secara in vitro (Tabel 4). Hal ini menunjukkan bahwa $\mathrm{SgP}$ memiliki resistansi tinggi terhadap perubahan ekstrem $\mathrm{pH}$, suhu, pengadukan, dan aktivitas enzimatis (BeMiller dan Whistler, 2009; Haub et al., 2010). Keadaan tersebut menjadikan $\mathrm{SgP}$ berpotensi sebagai suatu bioadsorben $\mathrm{Hg}(\mathrm{II})$. Bioadsorpsi $\mathrm{Hg}(\mathrm{II})$ oleh $\mathrm{SgP}$ minimum pada $\mathrm{pH}$ 1,50 (asam lambung). Hal ini disebabkan pada $\mathrm{pH}$ asam terjadi kompetitif Tabel 4. Resistensi Sg dan SgP dalam sistem in vitro sistem pencernaan manusia (a-amilase $\sim 500$ IU ditambahkan pada saat pH $\sim 6,80$ ) dengan ion $\mathrm{H}^{+}$(Igura dan Okazaki, 2010). Hal ini diduga ion $\mathrm{H}^{+}$ tersebut merupakan asam keras yang lebih mudah berinteraksi dengan gugus fosfat pada SgP sebagai pasangan asam-basa keras (Lippard dan Berg, 1994).

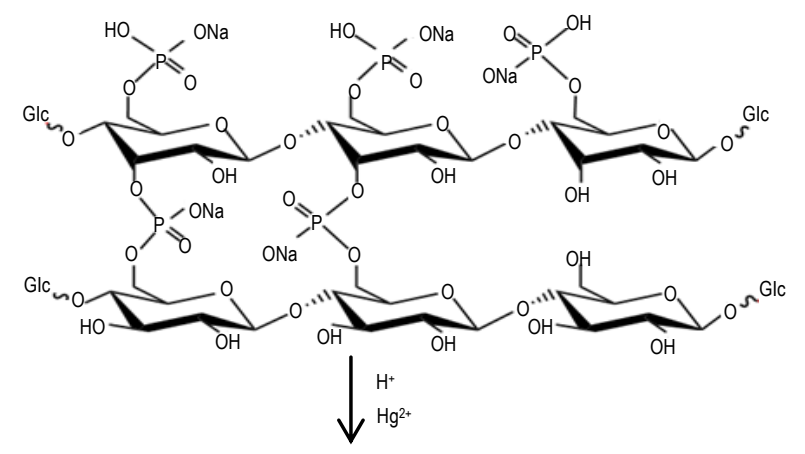

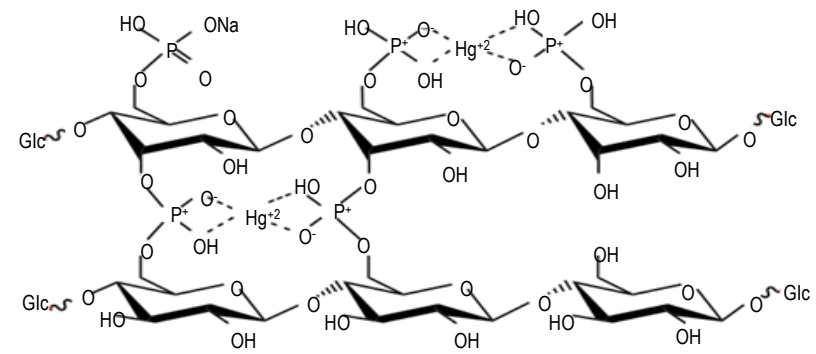

Gambar 3. Mekanisme terusulkan terhadap bioadsorpsi $\mathrm{Hg}(\mathrm{II})$ oleh $\mathrm{SgP}$

Pada studi ini, kesetimbangan adsorpsi terjadi pada $\mathrm{pH}$ $\sim 5,80-8,60$. Hal ini diduga pada $\mathrm{pH}$ tersebut ion-ion $\mathrm{Hg}$ (II) telah jenuh terikat pada gugus $\mathrm{HPO}_{3}$ pada $\mathrm{SgP}$. Faktor lainnnya yang dapat diduga adalah terjadinya hidrolisis sebagian rantai polimer SgP menjadi D-glukosa. Selain itu, tercapainya kondisi maksimum bioadsorpsi $\mathrm{Hg}(\mathrm{II})$ pada $\mathrm{pH} \sim 8,60$ diduga akibat terjadinya hidrolisis ester fosfat yang umumnya terjadi pada $\mathrm{pH}$ $\sim 8,60$ dalam sistem pencernaan manusia yang biasanya dikatalisis oleh fosfatase (Murray et al., 2003). 


\begin{tabular}{cccccccccc}
\hline Perlakuan & $\mathrm{pH}=1,50$ & $\mathrm{pH}=6,80$ & $\mathrm{pH}=5,80$ & $\mathrm{pH}=8,60$ & Perlakuan & $\mathrm{pH}=1,50$ & $\mathrm{pH}=6,80$ & $\mathrm{pH}=5,80$ & $\mathrm{pH}=8,60$ \\
\hline & D-glukosa & D-glukosa & D-glukosa & D-glukosa & & D-glukosa & D-glukosa & D-glukosa & D-glukosa \\
Sampel & & + & & & & Sampel & & & \\
$\mathrm{Sg}^{*}$ & + & + & ++ & +++ & $\mathrm{SgP} 1$ & + & + & ++ & - \\
$\mathrm{Sg} 2$ & + & ++ & +++ & +++ & $\mathrm{SgP} 2$ & + & + & - & - \\
$\mathrm{Sg} 3$ & + & ++ & +++ & +++ & $\mathrm{SgP} 3$ & - & - & - & - \\
$\mathrm{Sg} 4$ & + & +++ & ++++ & ++++ & $\mathrm{SgP} 4$ & - & - & - & - \\
$\mathrm{Sg} 5$ & + & ++ & ++ & +++ & $\mathrm{SgP} 5$ & - & - & - & - \\
$\mathrm{Sg} 6$ & + & ++ & ++ & +++ & $\mathrm{SgP} 6$ & - & - & - & - \\
$\mathrm{Sg}$ & + & ++ & +++ & +++ & $\mathrm{SgP}$ & - & - & - & - \\
\hline
\end{tabular}

\section{Keterangan}

* angka 1-6 menyatakan kesetaraan nilai dengan 0,100-0,600 gram Sg dan SgP yang digunakan

** rasio banyaknya rasio endapan $\mathrm{Cu}_{2} \mathrm{O}$ yang terbentuk dengan uji Fehling hasil hidrolisis $\mathrm{Sg}$ dan $\mathrm{SgP}$ dalam sistem in vitro

Berdasarkan hal di atas, bioadsorpsi $\mathrm{Hg}(\mathrm{II})$ oleh $\mathrm{SgP}$ dinyatakan memiliki kinerja efektif. Adapun persentase adsorpsi optimum dan maksimum tersebut sebesar 20,84\% dan 31,39\%, secara berturut-turut (Gambar 4). Hal ini disebabkan bahwa pH efektif mencapai adsorpsi optimum dan maksimum $\mathrm{Hg}(\mathrm{II})$ umumnya terjadi serentak pada $\mathrm{pH} \sim 5,00$ dalam larutan berair (Farooq et al., 2010).

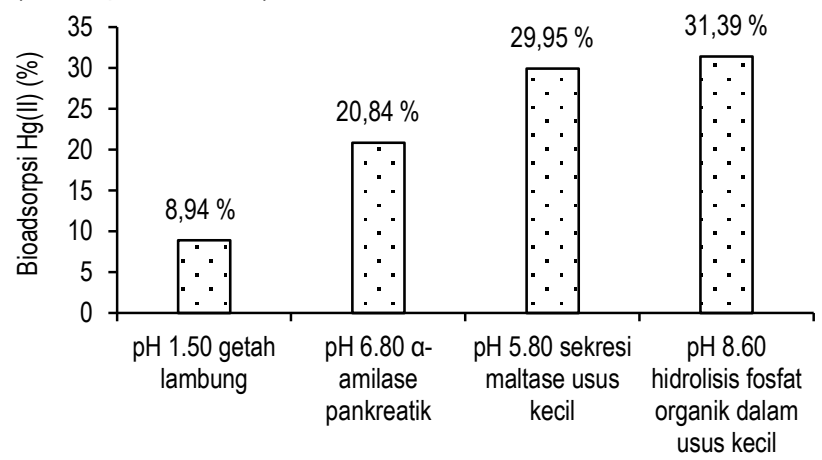

Gambar 4. Persentase bioadsorpsi $\mathrm{Hg}(\mathrm{II})$ oleh $\mathrm{SgP}$ secara in vitro sistem pencernaan manusia (massa $\mathrm{SgP}=\sim 0,300 \mathrm{~g}$ )

Pada penelitian ini, kapasitas biaodsorpsi $\mathrm{Hg}(\mathrm{II})$ oleh $\mathrm{SgP}$ secara in vitro memiliki kinerja yang baik dibandingkan beberapa tipe adsorben $\mathrm{Hg}(\mathrm{II})$ pada penelitian terdahulu (Tabel 5).

Tabel 5. Perbandingan nilai adsorpsi $\mathrm{Hg}(\mathrm{II})$ oleh beberapa adsorben termodifikasi

\begin{tabular}{lcc}
\hline \multicolumn{1}{c}{ Bioadsorben } & Q $(\mathrm{mg} / \mathrm{g})$ & Referensi \\
\hline Serabut kelapa termodifikasi tiol & 909,09 & Igwe et al., 2008 \\
Asam poli-y-glutamat & 96,79 & Inbaraj et al., 2009 \\
Karbon aktif & 18,87 & Amitava 2010 \\
Karbon aktif termodifikasi sulfur & 380,00 & Silva et al., 2010 \\
SgP & 104,63 & Penelitian ini \\
\hline
\end{tabular}

Keunggulan SgP pada penelitian ini disebabkan tingginya resistansi SgP sebagai pati fosfat yang tidak tercerna dalam sistem pencernaan manusia (BeMiller dan Whistler, 2009). Selain itu, kapasitas adsorpsi $\mathrm{Hg}(\mathrm{II})$ oleh $\mathrm{SgP}$ lebih tinggi daripada karbon aktif yang selama ini digunakan sebagai adsorben pada pencernaan manusia secara umum. Tingginya kapasitas adsorpsi $\mathrm{Hg}(\mathrm{II})$ oleh $\mathrm{SgP}$ dibandingkan karbon aktif diduga akibat adanya interaksi ion $\mathrm{Hg}(\mathrm{II})$ dengan gugus fosfat dan hidroksil pada SgP melalui ikatan kovalen. Kondisi tersebut tidak ditemukan pada karbon aktif yang hanya mampu menyerap ion-ion logam pada bagian pori (Amitava, 2010). Pada sisi lain, $\mathrm{SgP}$ memiliki nilai kapasitas adsorbsi $\mathrm{Hg}(\mathrm{II})$ yang lebih rendah daripada serabut kelapa termodifikasi tiol. Hal ini disebabkan gugus tiol merupakan spesi basa lunak yang tepat bagi ion $\mathrm{Hg}(\mathrm{II})$ yang merupakan suatu spesi asam lunak dibandingkan gugus fosfat yang terdapat pada SgP (Lippard dan Berg, 1994; lgwe et al., 2008).

\section{KESIMPULAN}

Kapasitas adsorpsi $\mathrm{Hg}(\mathrm{II})$ oleh $\mathrm{SgP}$ secara in vitro sistem pencernaan manusia mencapai $104,63 \mathrm{mg} / \mathrm{g}$. Nilai tersebut lebih tinggi dibandingkan karbon aktif yang selama ini digunakan sebagai adsorben secara umum pada tubuh manusia. Pada sisi lain, $\mathrm{SgP}$ memiliki nilai kapasitas adsorpsi $\mathrm{Hg}(\mathrm{II})$ yang lebih rendah dibandingkan adsorben lain yang termodifikasi turunan gugus tiol akibat adanya kesesuaian pasangan interaksi asam basa keras lunak.

\section{UCAPAN TERIMAKASIH}

Penulis mengucapkan terimakasih kepada Iman Sulaiman dari Fakultas Teknologi Pertanian Mayor Ilmu Pangan yang telah membantu dalam proses analisis viskosa cepat yang dilakukan pada penelitian ini.

\section{DAFTAR PUSTAKA}

Ahmad FB, Williams PA, Doublier JL, Durand S, Buleon A. 1999. Physico-chemical characterisation of sago starch. Carbohydr Polym 38: 361-370. DOI: 10.1016/S01448617(98)00123-4

Amitava S. 2010. Exploitation of Activated Carbon Materials for the Sorption of Mercury. [Dissertation]. Chennai. Department of Chemistry. Indian Institute of Technology Madras.

Aziz HA, Adlan MN, Arifin KS. 2008. Heavy metals (Cd, Pb, Zn, $\mathrm{Ni}, \mathrm{Cu}$ and $\mathrm{Cr}(\mathrm{III}))$ removal from water in Malaysia: Post treatment by high quality limestone. J Biotechnol 99: 15781583. DOl: 10.1016/.jiortech.2007.04.007. 
BeMiller J, Whistler R. 2009. Starch: Chemistry and Technology. $3^{\text {rd }}$ editions. Elsevier App. Sci. Publisher. New York. p. 646.

Blennow A, Nielsen TH, Baunsgaard L, Mikkelsen R, Engelsen SB. 2002. Starch phosporylation: a new front line in starch research. Trends in Plants Sci 7: 445-450. DOI: 10.1016/S1360-1385(02)02332-4

[BPBPI] Balai Penelitian Bioteknologi Perkebunan Indonesia. 2007. Tanaman sagu sebagai sumber energi alternatif. Warta Penelitian dan Pengembangan Pertanian 29: 3-4.

Chen CY, Yang C-Y, Chen A-H. 2011. Biosorption of $\mathrm{Cu}(\mathrm{II})$, $\mathrm{Zn}(\mathrm{II}), \mathrm{Ni}(\mathrm{II})$ and $\mathrm{Pb}(\mathrm{II})$ ions by cross-linked metal-imprinted chitosans with epichlorohydrin. J Env Man 92: 796-802. DOI: 10.1016/j.jenvman.2010.10.029.

Ding W, Zhao P, Li R. 2011. Removal of $\mathrm{Zn}(\mathrm{II})$ ions by dialdehyde-8-aminoquinoline starch from aqueous solution. Carbohydr Polym 83: 802-807. DOI: 10.1016/j.carbpol.2010.08.057.

Farooq U, Kozinski JA, Khan MA, Athar M. 2010. Biosorption of heavy metal ions using wheat based bioadsorbents- $A$ review of the recent literature. J Biotechol 101: 5043-5053. DOl: 10.1016/..biortech.2010.02.030.

Güney A, Arslankaya E, Tosun İ. 2007. Lead removal from aqueous solution by natural and pretreated clinoptilolite: Adsorption equilibrium and kinetics. J Haz Mat 146: 362371. DOI: 10.1016/i.jhazmat.2006.12.034.

Gupta N, Amritphale SS, Chandra N. 2010. Removal of Zn(II) from aqueous solution by using hybrid precursor of silicon and carbon. J Bio Technol 101: 3355-3362. DOI: 10.1016/i. biortech.2009.12.024.

Gyliene O, Visniakova S. 2008. Heavy metal removal from solutions using natural and synthetic sorbents. Env Res Eng and Manag 43: 28-34.

Igura M, Okazaki M. 2010. Cadmium sorption characteristics of phosphorylated sago starch-extraction residue. J Hazard Mater 178: 686-692. DOI: 10.1016/j.jhazmat.2010.01.142.

Igwe JC, Abia AA, Ibeh CA. 2008. Adsorption kinetic and intraparticulate diffusivities of $\mathrm{Hg}, \mathrm{As}$, and $\mathrm{Pb}$ ions on unmodified and thiolated coconut fiber. Int $\mathrm{J}$ Environ Sci Tech 5: 83-92.

Inbaraj BS, Wang JS, Lu JF, Siao FY, Chen BH. 2009. Adsorption on toxic mercury(II) by an extracellular biopolymer poly(Y-glutamic acid). J Bioresource Technol 100: 200-207. DOI: 10.1016/j.biortech.2008.05.014.

Itodo $\mathrm{AU}$, Itodo HU. 2010. Sorption energy estimation using Dubinin-Radushkevich and Temkin adsorption isotherms. Life Sci J 7: 31-39.

Karim AA, Nadiha MZ, Chen FK, Phuah YP, Chui YM, Fazilah A. 2008. Pasting and retrogradation properties of alkali- treated sago (Metroxylon sagu) starch. Food Hydrocoll 22: 1044-1053. DOl: 10.1016/j.foodhyd.2007.05.011.

Li B-Z, Wang L-J, Li D, Chiu YL, Zhang Z-J, Shi J, Chen XD, Mao Z-H. 2009. Physical properties and loading capacity of starch-based microparticles crosslinked with trisodium trimetaphospate. J Food Eng 92: 255-260. DOl: 10.1016/j.jfoodeng.2008.10.008.

Lippard SJ, Berg JM. 1994. Principles of Bioinorganic Chemistry. University Science Books. California. p. 22.

Manoi K, Rizvi SSH. 2010. Physicochemical characteristics of phosphorylated cross-linked starch produced by reactive supercritical fluid extrusion. Carbohydr Polym 81: 687-694. DOI: 10.1016/j.carbpol.2010.03.042.

Murray RK, Granner DK, Mayes PA, Rodwell VW. 2003. Biokimia Harper. Edisi ke-25. Hartono A (alih bahasa). EGC. Jakarta. p. 660.

Romengga J, Irawadi TT, Djulaika R, Zakaria A, Muntamah, 2011. Sintesis pati taut silang fosfat berderajat substitusi tinggi dalam suasana asam. J Teknol dan Industri Pangan 18: 117-123.

Silva HS, Ruiz SV, Granados DL, Santángelo JM. 2010. Adsorption of mercury(II) from liquid solutions using modified activated carbons. Mat Res 13: 129-134. DOl: 10.1590/S1516-14392010000200003.

Silverstein RM, Webster FX, Kiemle DJ. 2005. Spectrometric Identification of Organic Compounds. $7^{\text {th }}$ editions. John Wiley dan Sons. New Jersey. p. 124.

Wan MW, Kan CC, Rogel BD, Dalida MLP. 2010. Adsorption of copper (II) and lead (II) ions from aqueous solution on chitosan-coated sand. Carbohydr Polym 80: 891-899. DOI: 10.1016/j.carbpol.2009.12.048.

Wan Ngah WS, Teong LC, Hanafiah MAKM. 2011. Adsorption of dyes and heavy metal ions by chitosan composites: A review. Carbohydr Polym 83: 1446-1456. DOI: 10.1016/i.carbpol.2010.11.004.

Wanrosli WD, Rohaizu R, Ghazali A. 2011. Synthesis and characterization of cellulose phosphate from oil palm empty fruit bunches microcrystalline cellulose. Carbohydr Polym 84: 262-267. DOI: 10.1016/i.carbpol.2010.11.032.

Xing G-x, Zhang S-f, Ju B-z, Yan J-z. 2006. Study on adsorption behavior of crosslinked cationic starch maleate for chromium(VI). Carbohydr Polym 66: 246-251. DOl: 10.1016/j.carbpol.2006.03.005.

Zakhama S, Dhaouadi H, M'Henni F. 2011. Nonlinear modelisation of heavy metal removal from aqueous solution using Ulva lactuca algae. J Bioresource Technol 102: 786796. $\quad$ DOI: 10.1016/j.biortech.2010.08.107. 